\title{
Improvement of the Gas Sensing Properties in Nanostructured $\mathrm{Gd}_{0.9} \mathrm{Sr}_{0.1} \mathrm{CoO}_{3}$
}

\author{
Carlos R. Michel' ${ }^{1}$, Narda L. López Contreras ${ }^{1}$, Edgar R. López-Mena ${ }^{1}$, \\ Juan Carlos Ibarra ${ }^{1}$, Arturo Chávez-Chávez ${ }^{1}$ and Mauricio Ortiz-Gutiérrez ${ }^{2}$ \\ ${ }^{1}$ Universidad de Guadalajara, CUCEI, \\ 2Universidad Michoacana de San Nicolás de Hidalgo, \\ México
}

\section{Introduction}

Global warming has become one of the most important issues worldwide (Kerr, 2007). The emission of large amounts of $\mathrm{CO}_{2}$ has been identified as its main cause (Karl et al., 2003; Parry et al., 2008). In order to determine the concentration of this and other polluting gases, researchers around the world have developed solid state chemical sensors. Even though $\mathrm{SnO}_{2}, \mathrm{ZnO}, \mathrm{TiO}_{2}$ and $\mathrm{WO}_{3}$ have been some of the most studied gas sensor materials, other oxides, with unique physical and chemical properties are also appropriate for this application (Yamazoe, 2005). Ternary and quaternary oxides, whose crystal structures are the perovskite or spinel, have notable electrical and catalytical properties, useful for gas sensing purposes (Brosha et al., 2000; Dutta et al., 2004; Kong et al., 1996; Kosacki et al., 1998; Post et al., 1999; Suo et al., 1997).

$\mathrm{GdCoO}_{3}$ is a semiconductor material, having the perovskite-type structure. It possess outstanding physical and physicochemical properties like magnetotransport, thermoelectricity, mixed ionic-electronic conductivity for solid oxide fuel cells, photocatalytical activity for the decomposition of dyes and phenols, and gas sensing activity (Rey-Cabezudo et al., 2002; Moon et al., 2000; Takeda et al., 1996; Wienhöfer et al., 2004; Mahata et al., 2007; Michel et al., 2009).

In this work, samples of $\mathrm{Gd}_{1-\mathrm{x}} \mathrm{Sr}_{\mathrm{x}} \mathrm{CoO}_{3}(\mathrm{x}=0,0.1)$ were prepared by two different methods. The main goals were to study the effect of chemical composition and microstructure on the gas sensing properties. The effect of the chemical composition was approached through strontium doping, and the effect of the microstructure was analyzed by preparing samples with different particle size. The preparation of $\mathrm{Gd}_{1-x} \mathrm{Sr}_{\mathrm{x}} \mathrm{CoO}_{3}$ powders was made in aqueous media, using the solution and solution-polymerization methods.

In recent years, the development of nanomaterials has attracted the attention of many research groups around the world. In order to decrease the particle size of ceramic materials, the use of polymerizing agents, such as polyvinyl alcohol and polyethylene glycol has been previously reported in the literature (Lee et al., 1998; Gülgün et al., 1999). A wide variety of nanostructured materials, such as cordierite, monoclinic yttrium 
aluminate, portland cement components, hydroxyapatite, and many more, have been synthesized by this method.

On the other hand, nanostructured materials provide large specific surface areas; which increases the interaction between the sensor surface and the surrounding gases. Therefore, in this work, the gas sensing properties of $\mathrm{Gd}_{1-x} \mathrm{Sr}_{x} \mathrm{CoO}_{3}$ powders were evaluated. This characterization was done by using direct and alternating current on $\mathrm{Gd}_{1-x} \mathrm{Sr}_{x} \mathrm{CoO}_{3}$ thick films.

\section{Experimental}

$\mathrm{GdCoO}_{3}$ was synthesized by a solution-polymerization method, using stoichiometric amounts of $\mathrm{Gd}\left(\mathrm{NO}_{3}\right)_{3} 6 \mathrm{H}_{2} \mathrm{O}$ (Alfa Aesar) and $\mathrm{Co}\left(\mathrm{NO}_{3}\right)_{3} 6 \mathrm{H}_{2} \mathrm{O}$ (J.T. Baker). The reagents were dissolved in $100 \mathrm{ml}$ of deionized water. To promote the polymerization effect, $0.44 \mathrm{~g}$ of polyvinyl alcohol (PVA, Alfa Aesar) and $3.2 \mathrm{~g}$ of sucrose (Alfa Aesar) were dissolved in 100 $\mathrm{ml}$ of deionized water. Due to the poor solubility of PVA in cool water, the water was preheated at $60^{\circ} \mathrm{C}$. All the solutions were mixed under strong stirring for $2 \mathrm{~h}\left(60^{\circ} \mathrm{C}\right)$; Fig. $1 \mathrm{~A}$ shows a typical solution obtained after this process. $\mathrm{Gd}_{0.9} \mathrm{Sr}_{0.1} \mathrm{CoO}_{3}$ was prepared by the solution and solution-polymerization methods. Similarly to the previous synthesis, stoichiometric amounts of gadolinium, cobalt and strontium nitrates $\left(\mathrm{Sr}\left(\mathrm{NO}_{3}\right)_{2}\right.$ (Alfa Aesar)) were dissolved in $100 \mathrm{ml}$ of deionized water. By the solution method, $0.1 \mathrm{~mol}$ of citric acid (Alfa Aesar) was added to the nitrate solution. In the case of the solution-polymerization, the process previously described was used. Then, water evaporation was done by using microwave radiation; a domestic microwave oven (Panasonic) was used. The materials obtained after the microwave-assisted evaporation are shown in: Fig. 1B (solution method) and Fig. 1C (solution-polymerization). In the latter, a dry solid having extensive porosity was produced.
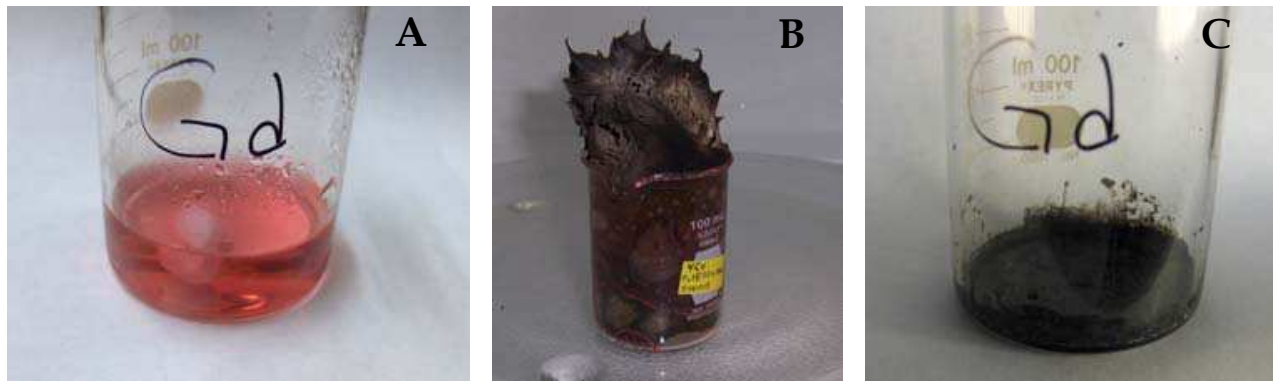

Fig. 1. (A) Aqueous solution obtained by solution-polymerization. Materials obtained after water evaporation: (B) solution and (C) solution-polymerization.

In order to obtain single-phase $\mathrm{GdCoO}_{3}$ and $\mathrm{Gd}_{0.9} \mathrm{Sr}_{0.1} \mathrm{CoO}_{3}$ powders, the precursors were calcined in the range of 550 to $800^{\circ} \mathrm{C}$. The resulting powders were analyzed by X-ray powder diffraction (XRD), at room temperature, using a Rigaku Miniflex apparatus. $\mathrm{Cu} \mathrm{K}_{\alpha 1}$ radiation $(1.5405 \AA)$ was used. The surface morphology of the powders was observed by scanning electron microscopy (SEM), using a Jeol JSM-5400LV microscope, in secondary electron mode. For the identification of nanoparticles, transmission electron microscopy 
(TEM, Jeol JEM-1010) was used. Thick films of $\mathrm{GdCoO}_{3}$ and $\mathrm{Gd}_{0.9} \mathrm{Sr}_{0.1} \mathrm{CoO}_{3}$ were prepared by depositing a suspension of the powders on alumina discs. In this process, $\sim 0.5 \mathrm{~g}$ of each powder was dispersed in $2 \mathrm{ml}$ of isopropyl alcohol, using ultrasonic vibration. Then, the suspension was poured on alumina substrates, producing films with $3 \mathrm{~mm}$ diameter and $\sim 400 \mu \mathrm{m}$ thickness. The electrical contacts were made with high-purity silver wires (diameter $0.2 \mathrm{~mm}$ ). Fig. 2 shows a scheme of the gas sensor device.
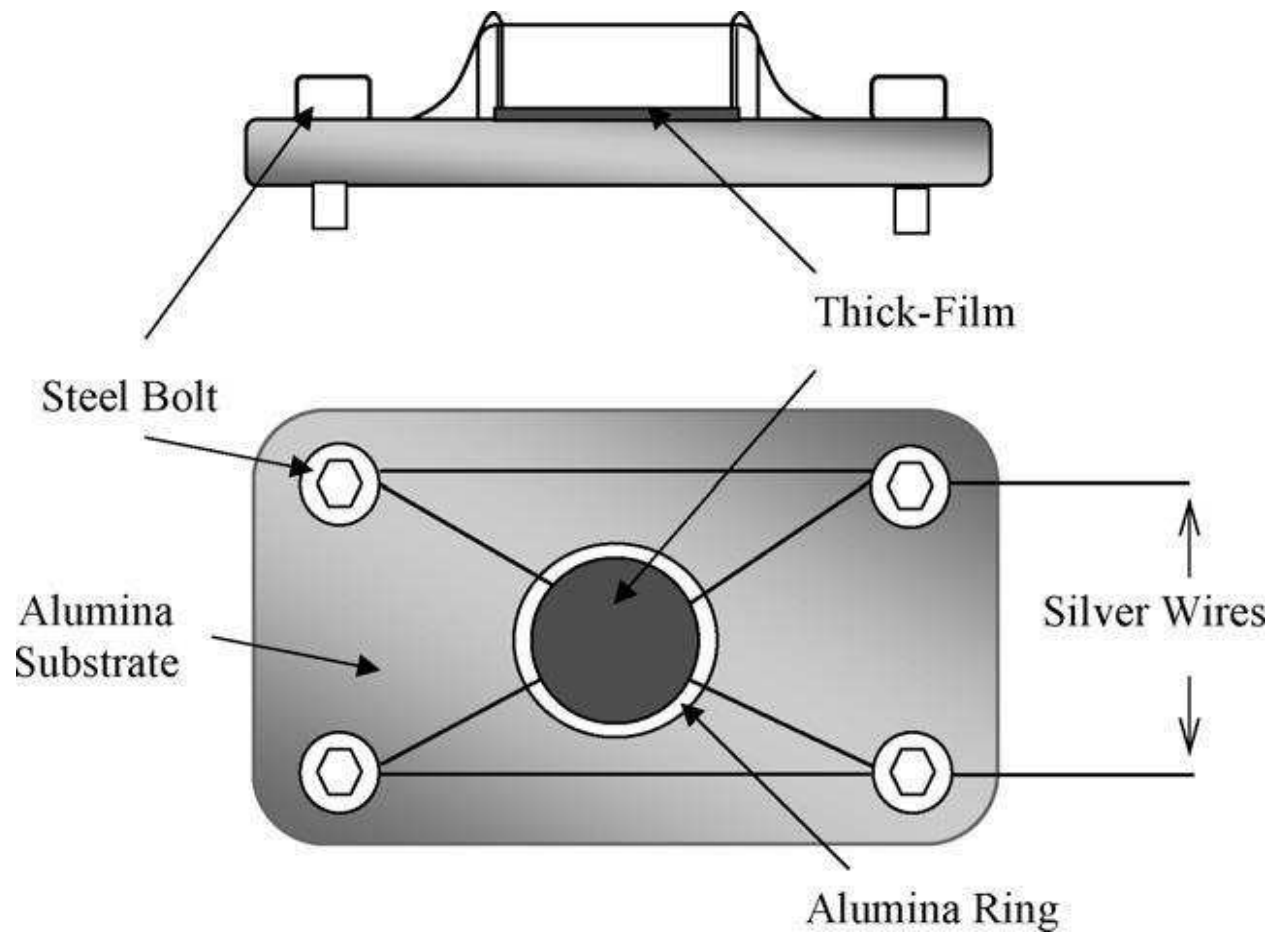

Fig. 2. Schematic illustration of the gas sensor device.

Electrical characterization was carried out by the two-point probe method, using a tube-type furnace having programmable temperature control. The direct current measurements (DC) were obtained by using a digital data acquisition unit (Agilent 34970A), having a multiplexer module. A digital voltmeter (Agilent 34401A) was also used. The polarization curves were recorded from $-5 \mathrm{~V}$ to $5 \mathrm{~V}$, using a Solartron $1285 \mathrm{~A}$ potentiost/galvanostat. The alternating current characterization $(\mathrm{AC})$ was performed by measuring the magnitude of the impedance $(|Z|)$, with a LCR meter (Agilent 4263B). The graphs were obtained using the LabView 8.6 software (National Instruments).

The gases $\left(\mathrm{CO}_{2}, \mathrm{O}_{2}\right.$ and extra dry compressed air) were supplied by using a mass flow controller (647C, MKS Instruments). Fig. 3 shows a diagram of the experimental setup and Fig. 4 shows an image of the actual instruments. It is important to mention that in this work the experimental setup was not pressurized; then, the pressure of the test chamber was slightly above 1013 milibars. 


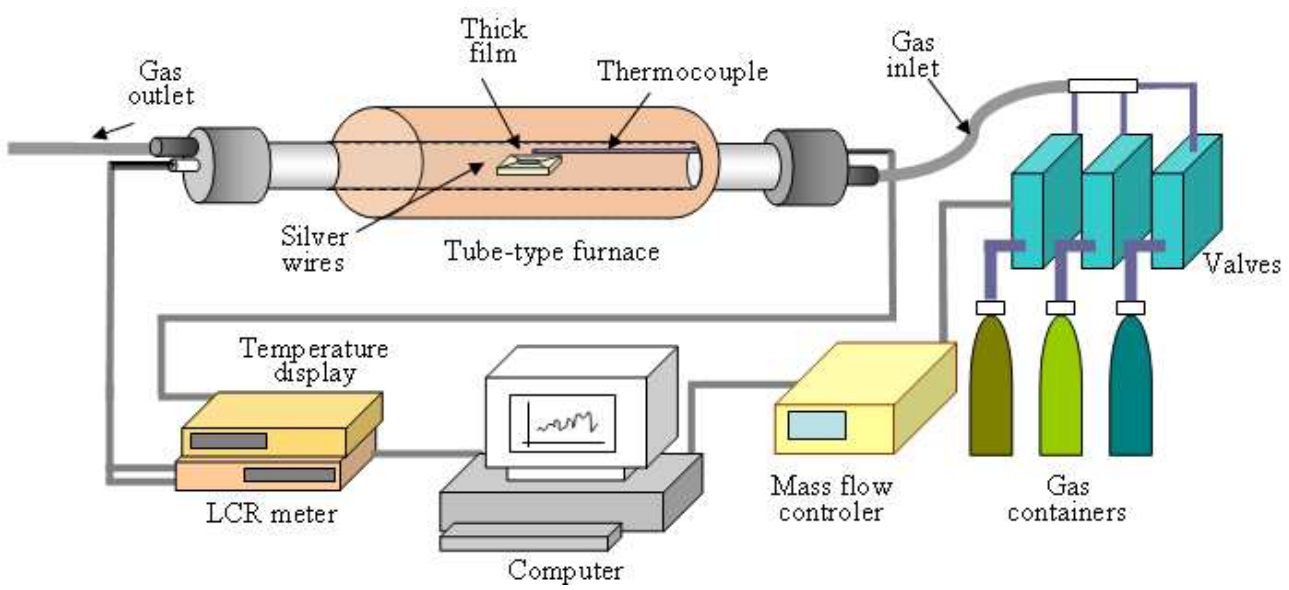

Fig. 3. Diagram of the experimental setup used for the gas sensing characterization.

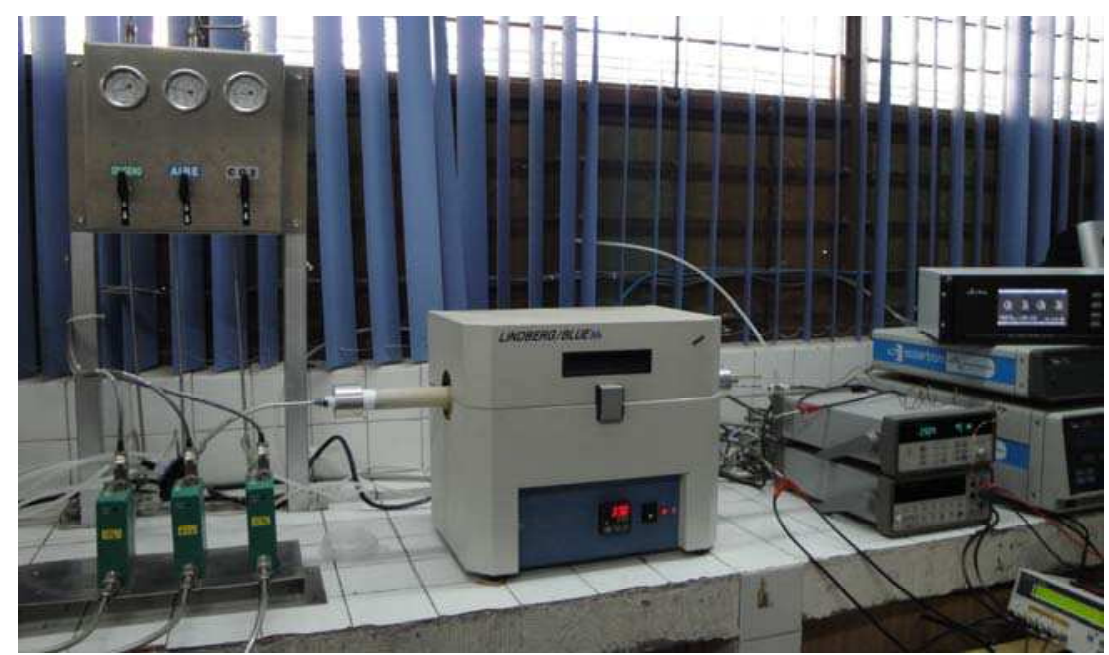

Fig. 4. Image of the instruments used for the gas sensing measurements.

\section{Results}

\subsection{X-ray powder diffraction}

Fig. 5 shows the XRD patterns of the precursor powder of $\mathrm{GdCoO}_{3}$ calcined from 550 to $750^{\circ} \mathrm{C}$ in air. The calcination at $550^{\circ} \mathrm{C}$ produced no crystalline materials; however, at $600^{\circ} \mathrm{C}$ the main diffraction lines of $\mathrm{Gd}_{2} \mathrm{O}_{3}$ and $\mathrm{Co}_{3} \mathrm{O}_{4}$ were identified by using the JCPDF files 0120797 and $043-1003$ respectively. The calcination at $650^{\circ} \mathrm{C}$ revealed that the diffraction lines of $\mathrm{Gd}_{2} \mathrm{O}_{3}$ and $\mathrm{Co}_{3} \mathrm{O}_{4}$ are still present; however, the main diffraction line of $\mathrm{Gd}_{0.9} \mathrm{Sr}_{0.1} \mathrm{CoO}_{3}$ can

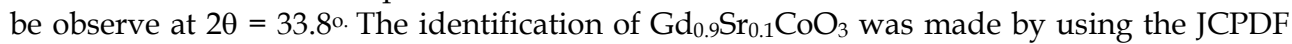
file 25-1057, which indeed corresponds to $\mathrm{GdCoO}_{3}$; however, these oxides have the same crystal structure. However, it should be consider that the amount of gadolinium that can be 
replaced by strontium is small, because their ionic radii are $0.94 \AA$ (Gd) and $1.16 \AA$ (Sr). The calcination at $700{ }^{\circ} \mathrm{C}$ increased the reaction rate between $\mathrm{Gd}_{2} \mathrm{O}_{3}$ and $\mathrm{Co}_{3} \mathrm{O}_{4}$, producing a larger amount of $\mathrm{Gd}_{0.9} \mathrm{Sr}_{0.1} \mathrm{CoO}_{3}$. Firing at $750^{\circ} \mathrm{C}$ yielded near single-phase $\mathrm{Gd}_{0.9} \mathrm{Sr}_{0.1} \mathrm{CoO}_{3}$, as it can be observed in the corresponding pattern. The Miller indices of each plane were assigned according to the JCPDF card.

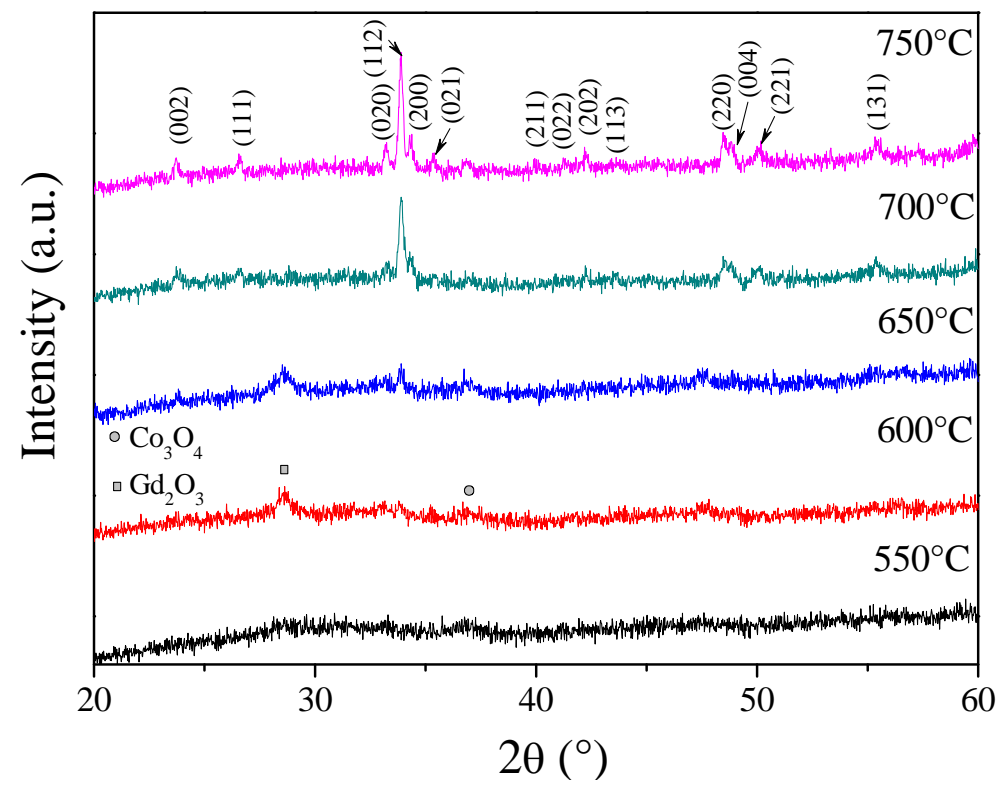

Fig. 5. X-ray powder diffraction patterns of $\mathrm{GdCoO}_{3}$ obtained by solution-polymerization method, calcined at various temperatures.

Figure 6 shows the crystal structure evolution as temperature increased from 600 to $800^{\circ} \mathrm{C}$. The calcination at $600{ }^{\circ} \mathrm{C}$ produced a mixture $\mathrm{Gd}_{2} \mathrm{O}_{3}, \mathrm{Co}_{3} \mathrm{O}_{4}$ and $\mathrm{Gd}_{0.9} \mathrm{Sr}_{0.1} \mathrm{CoO}_{3}$, being the latter the main crystalline phase. At $700^{\circ} \mathrm{C}$, a significant increase of $\mathrm{Gd}_{0.9} \mathrm{Sr}_{0.1} \mathrm{CoO}_{3}$ can be noticed; however, the main diffraction line of $\mathrm{Gd}_{2} \mathrm{O}_{3}$, placed at $2 \theta=28.6^{\circ}$ is present. The calcination at $800^{\circ} \mathrm{C}$ produced almost single-phase $\mathrm{Gd}_{0.9} \mathrm{Sr}_{0.1} \mathrm{CoO}_{3}$. Comparing these results with those obtained for $\mathrm{GdCoO}_{3}, \mathrm{Gd}_{0.9} \mathrm{Sr}_{0.1} \mathrm{CoO}_{3}$ appears at a lower calcination temperature;

Fig. 7 shows X-ray diffraction patterns obtained from precursor powders of $\mathrm{Gd}_{0.9} \mathrm{Sr}_{0.1} \mathrm{CoO}_{3}$ (solution-polymerization), calcined at different temperatures. The calcination at $550{ }^{\circ} \mathrm{C}$ produced an amorphous solid; however, at $600^{\circ} \mathrm{C}$ nearly single-phase $\mathrm{Gd}_{0.9} \mathrm{Sr}_{0.1} \mathrm{CoO}_{3}$ was produced. Increasing the calcination temperature to $700^{\circ} \mathrm{C}$ produced no perceptible changes in the XRD patterns. Comparing the sequence of XRD patterns of Fig. 7, with those displayed in Fig. 6, the solution-polymerization method decreased the temperature at which $\mathrm{Gd}_{0.9} \mathrm{Sr}_{0.1} \mathrm{CoO}_{3}$ can be formed. Besides, Fig. 7 does not display diffraction lines of $\mathrm{Gd}_{2} \mathrm{O}_{3}$ and $\mathrm{Co}_{3} \mathrm{O}_{4}$, indicating that the formation and further reaction of these oxides does not occur. The interaction, at molecular scale, of gadolinium, strontium and cobalt ions, could be an explanation of the formation of $\mathrm{Gd}_{0.9} \mathrm{Sr}_{0.1} \mathrm{CoO}_{3}$ at lower temperature. Evidently the solutionpolymerization method provides a notable save of energy in the preparation of ceramics, by using an inexpensive polymeric precursor. 


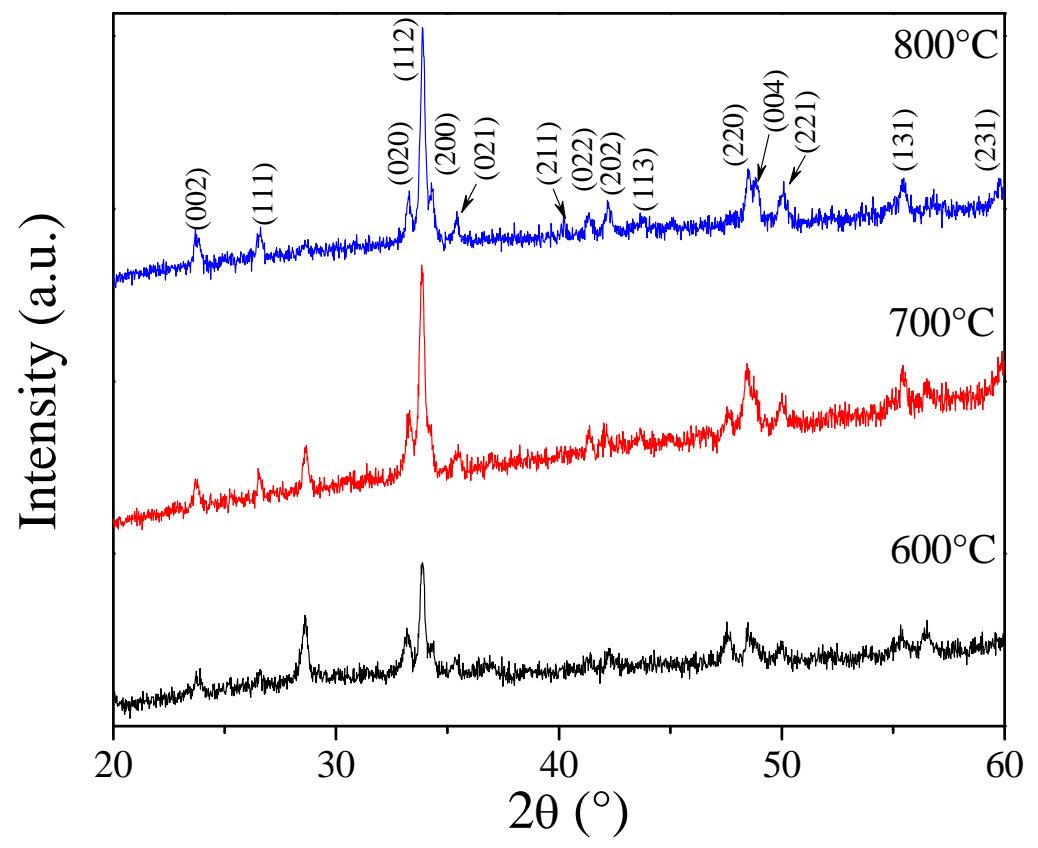

Fig. 6. Crystal structure evolution with temperature of $\mathrm{Gd}_{0.9} \mathrm{Sr}_{0.1} \mathrm{CoO}_{3}$ prepared by the solution method.

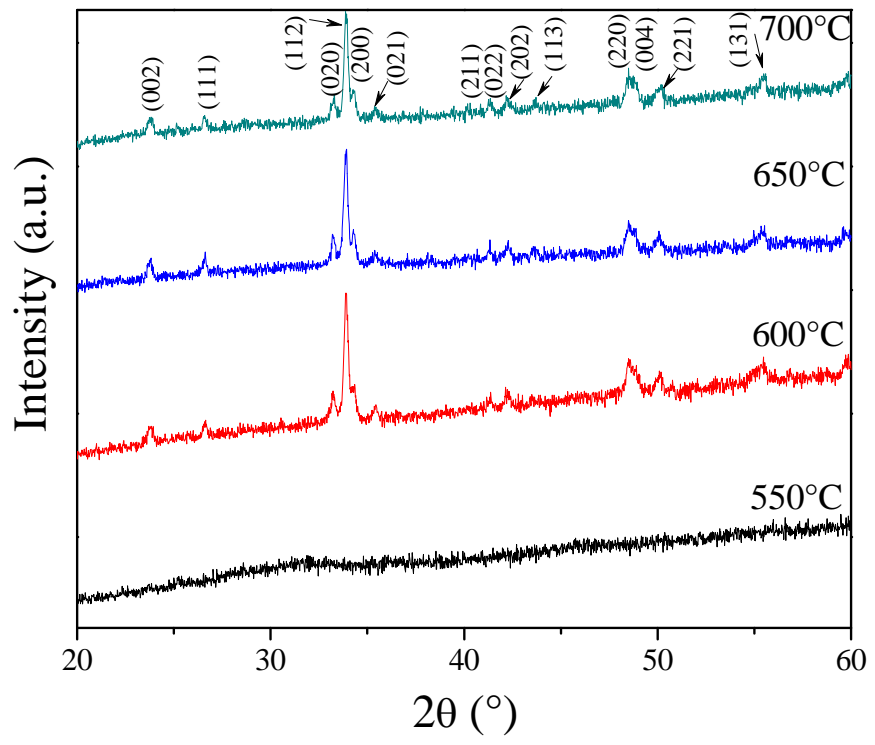

Fig. 7. X-ray powder diffraction patterns of $\mathrm{Gd}_{0.9} \mathrm{Sr}_{0.1} \mathrm{CoO}_{3}$ obtained by solutionpolymerization, calcined at various temperatures. 


\subsection{Scanning electron microscopy}

Fig. 8 shows the typical surface morphology (SEM) of powders of $\mathrm{GdCoO}_{3}$ calcined at: (A) $550,(B) 600,(C) 650,(D) 700$ and (E) 750 ${ }^{\circ} \mathrm{C}$. The microstructure of samples calcined from 550 to $700^{\circ} \mathrm{C}$ was of thin laminas having smooth surface and semispherical cavities. The entire solids possess extensive porosity. The sample calcined at $750^{\circ} \mathrm{C}$ shows a slight different microstructure, because a granular shape can be noticed. This feature can be explained by the sintering process occurred at higher temperature. The observation of this sample by TEM will provide a better insight of the microstructure of this sample, as will be shown later in this chapter.
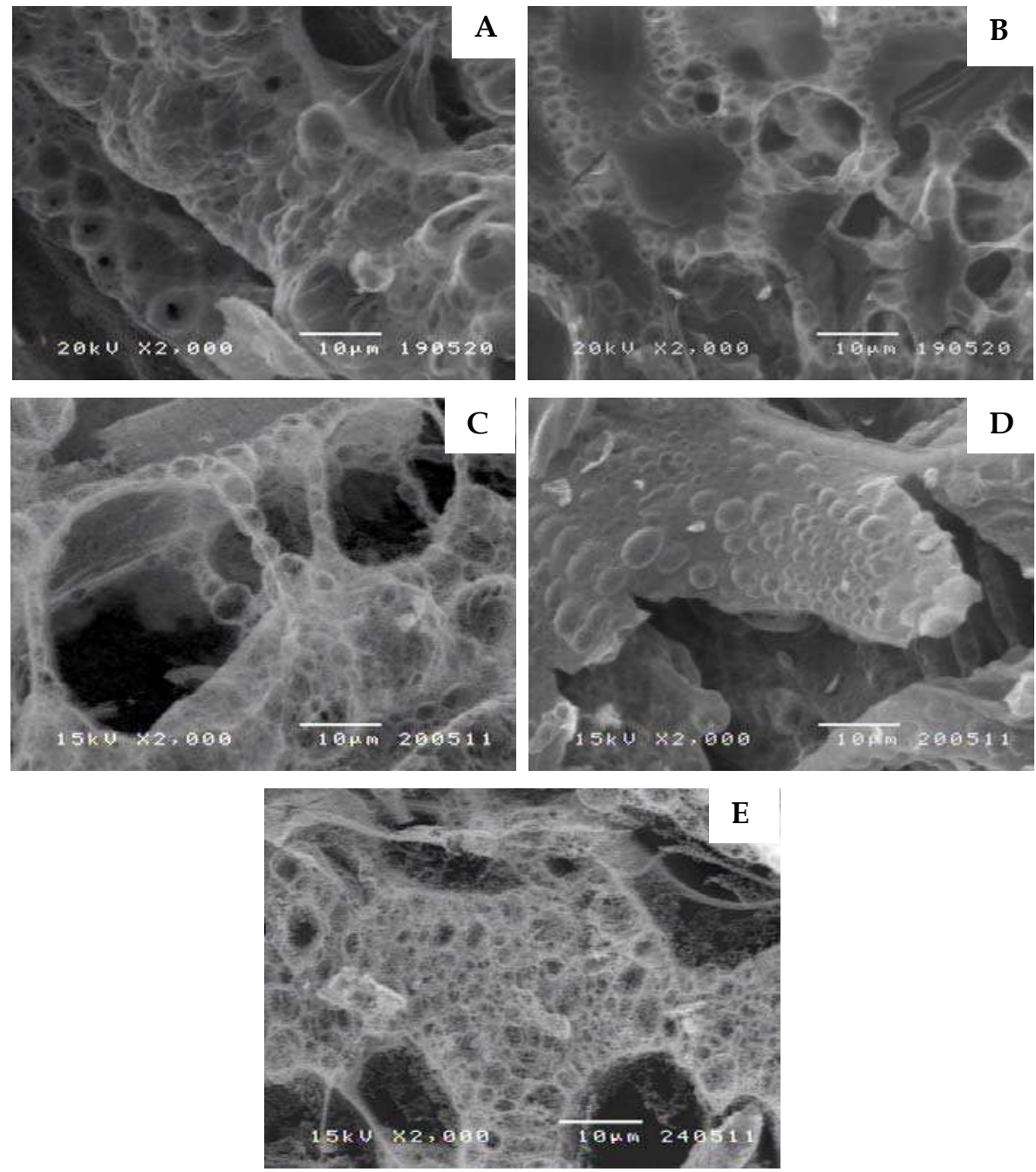

Fig. 8. SEM images of $\mathrm{GdCoO}_{3}$ powder calcined at: A) $\left.\left.\left.550^{\circ} \mathrm{C}, \mathrm{B}\right) 600^{\circ} \mathrm{C}, \mathrm{C}\right) 650^{\circ} \mathrm{C}, \mathrm{D}\right) 700^{\circ} \mathrm{C}$ and E) $750^{\circ} \mathrm{C}$, in air. 
Fig. 9 shows the surface microstructure of $\mathrm{Gd}_{0.9} \mathrm{Sr}_{0.1} \mathrm{CoO}_{3}$ samples (solution method), calcined at A) $600^{\circ} \mathrm{C}$, B) $700^{\circ} \mathrm{C}$ and C) $800^{\circ} \mathrm{C}$. These SEM images revealed that the increase in the calcination temperature had little effect on the surface microstructure. All the samples show no relevant features; however, in order to determine if this material is composed by nanoparticles, further observation by TEM was performed.
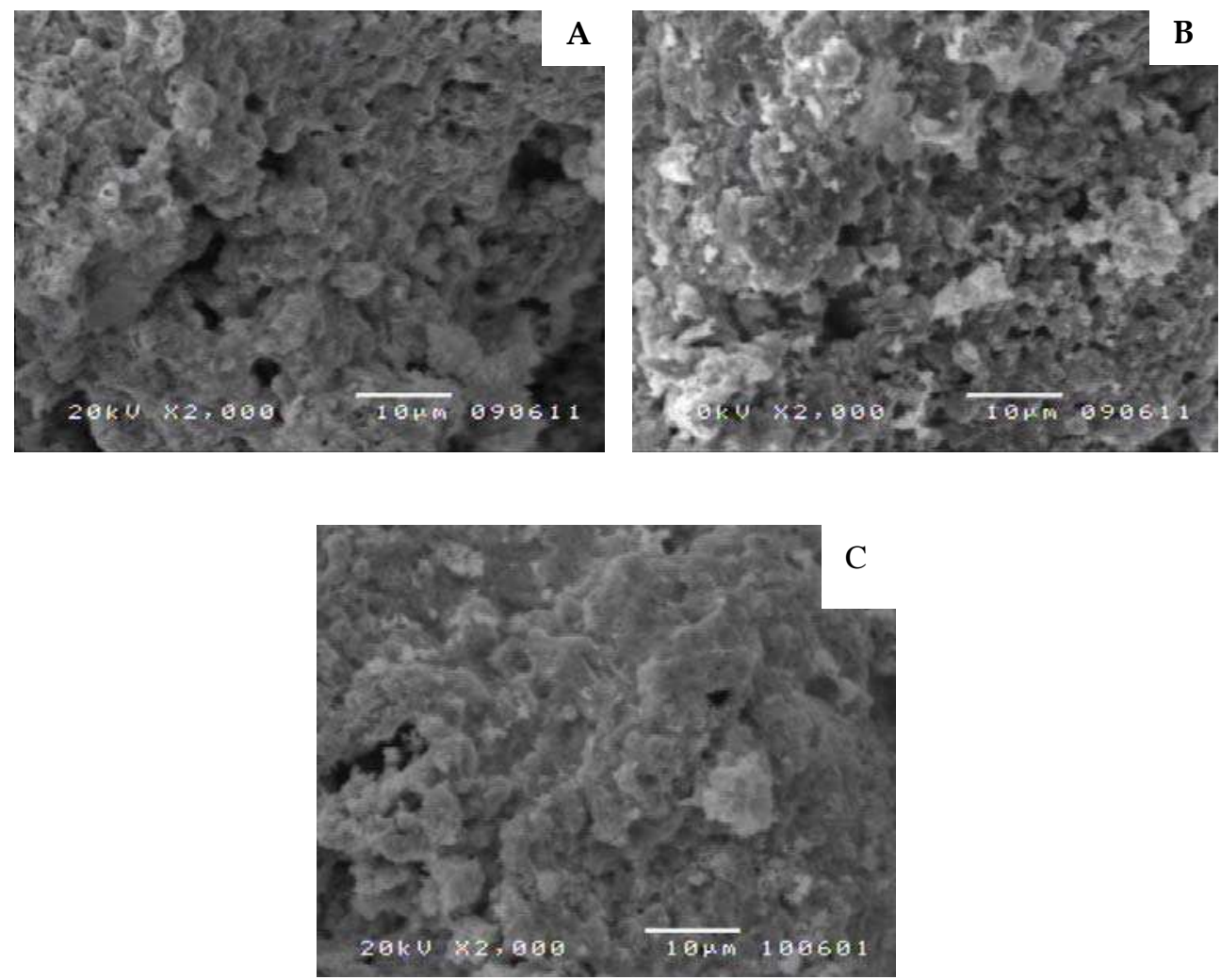

Fig. 9. SEM image of $\mathrm{Gd}_{0.9} \mathrm{Sr}_{0.1} \mathrm{CoO}_{3}$ (solution method) calcined at: A) $\left.600^{\circ} \mathrm{C}, \mathrm{B}\right) 700^{\circ} \mathrm{C}$ and $\mathrm{C}$ ) $800^{\circ} \mathrm{C}$, in air.

Fig. 10 shows SEM photos of $\mathrm{Gd}_{0.9} \mathrm{Sr}_{0.1} \mathrm{CoO}_{3}$ synthesized by the solution-polymerization route, calcined at: A) $550^{\circ} \mathrm{C}$, B) $600^{\circ} \mathrm{C}$, C) $650^{\circ} \mathrm{C}$ and D) $700^{\circ} \mathrm{C}$. A highly porous material, having smooth surfaces was produced. By increasing the calcination temperature, the microstructure of the samples was not altered. Comparing these images with those obtained for $\mathrm{Gd}_{0.9} \mathrm{Sr}_{0.1} \mathrm{CoO}_{3}$ (the solution method), significant differences can be noticed. The use of a polymerizing agent in aqueous solution produced at least a solid with high porosity. Due to $\mathrm{Gd}_{0.9} \mathrm{Sr}_{0.1} \mathrm{CoO}_{3}$ prepared by solution-polymerization can be indeed formed by nanoparticles its observation by TEM was also done. 

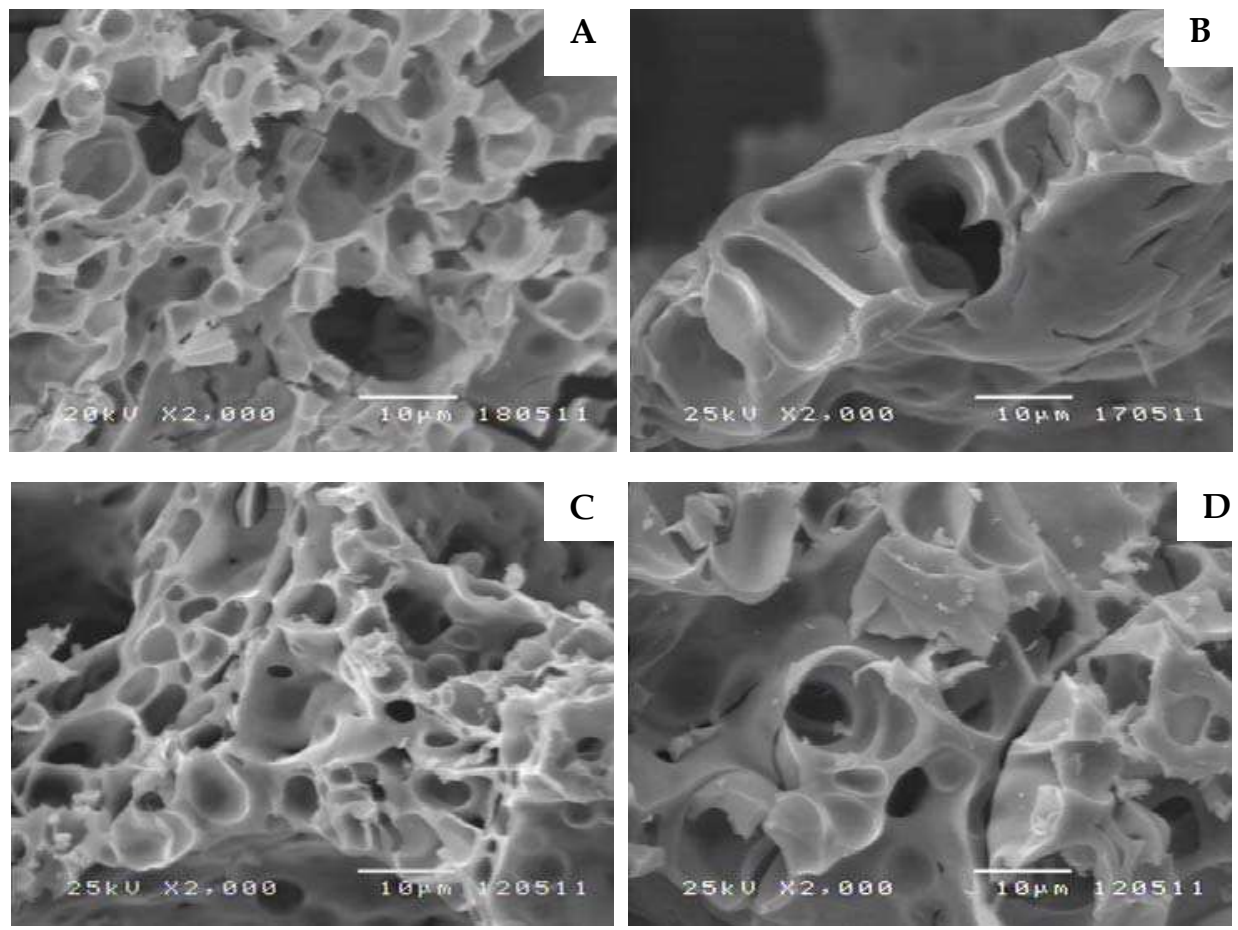

Fig. 10. SEM images of $\mathrm{Gd}_{0.9} \mathrm{Sr}_{0.1} \mathrm{CoO}_{3}$ prepared by solution-polymerization: A) $550^{\circ} \mathrm{C}, \mathrm{B}$ ) $\left.600^{\circ} \mathrm{C}, \mathrm{C}\right) 650^{\circ} \mathrm{C}$ and D) $700^{\circ} \mathrm{C}$.

\subsection{Transmission electron microscopy}

TEM in bright-field mode was used to examine samples of single phase $\mathrm{GdCoO}_{3}$ and $\mathrm{Gd}_{0.9} \mathrm{Sr}_{0.1} \mathrm{CoO}_{3}$ (both methods). Fig. 11 shows TEM images of: A) $\mathrm{GdCoO}_{3}$, synthesized by the solution-polymerization method, calcined at $750^{\circ} \mathrm{C}$, B) $\mathrm{Gd}_{0.9} \mathrm{Sr}_{0.1} \mathrm{CoO}_{3}$ prepared by solution method, calcined at $800^{\circ} \mathrm{C}$, and $\mathrm{C}$ ) $\mathrm{Gd}_{0.9} \mathrm{Sr}_{0.1} \mathrm{CoO}_{3}$ prepared by solutionpolymerization $\left(650^{\circ} \mathrm{C}\right)$. Fig. 11A shows interconnected, rounded or semispherical particles, with size larger than $100 \mathrm{~nm}$. The formation of necks between these submicron particles was identified throughout the sample. Moreover, the interconnection between particles produced a rigid solid structure, with high porosity, which increases the contact surface between gaseous species and the perovskite.

Fig. 11B shows a typical TEM image of $\mathrm{Gd}_{0.9} \mathrm{Sr}_{0.1} \mathrm{CoO}_{3}$ powder prepared by solution method. It exhibits a similar microstructure than that observed for $\mathrm{GdCoO}_{3}$, having extensive connection among particles, forming a continuous solid. Fig. 11C displays the microstructure of $\mathrm{Gd}_{0.9} \mathrm{Sr}_{0.1} \mathrm{CoO}_{3}$ made by solution-polymerization. Compared to previous samples, a notable smaller particle size can be noticed; an average particle size of $45 \mathrm{~nm}$ was measured. Even though, nanoparticle agglomeration is present, abundant nanoporosity can be observed. It can be concluded that the solution-polymerization method reduced the energy expenditure in the preparation of $\mathrm{Gd}_{0.9} \mathrm{Sr}_{0.1} \mathrm{CoO}_{3}$, and produced a significant reduction in particle size. High porosity and high specific surface areas can be obtained by using this method. 

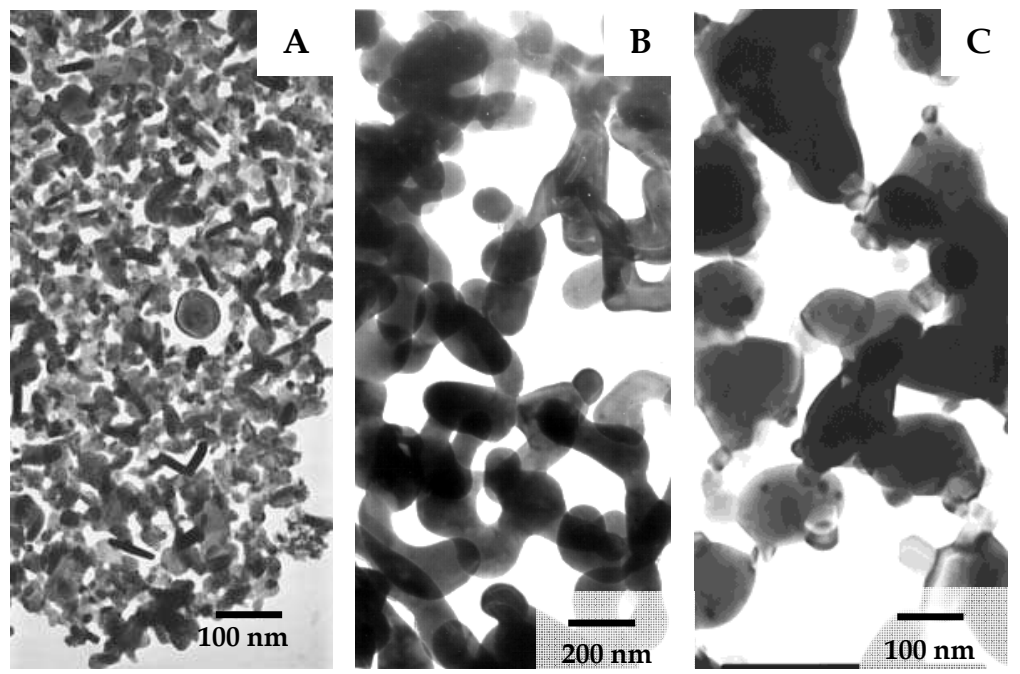

Fig. 11. TEM images of (A) $\mathrm{GdCoO}_{3}\left(750^{\circ} \mathrm{C}\right)$, (B) $\mathrm{Gd}_{0.9} \mathrm{Sr}_{0.1} \mathrm{CoO}_{3}$ prepared by solution method $\left(800^{\circ} \mathrm{C}\right)$, and $(\mathrm{C}) \mathrm{Gd}_{0.9} \mathrm{Sr}_{0.1} \mathrm{CoO}_{3}$ prepared by solution-polymerization $\left(650^{\circ} \mathrm{C}\right)$.

The abundant porosity of $\mathrm{Gd}_{0.9} \mathrm{Sr}_{0.1} \mathrm{CoO}_{3}$ (solution-polymerization) is associated to the evolution of carbon dioxide and steam during the thermal decomposition of the polymerized metal ion-chelated complex (Das, 2001). A large amount of heat is also produced in this process. Theoretically, one mole of sucrose delivers 23 moles of gases, which avoid particle agglomeration and produce extensive porosity and fine particles in the final product. The thermal decomposition of sucrose occurs by the following reaction:

$$
\mathrm{C}_{12} \mathrm{H}_{22} \mathrm{O}_{11}+12 \mathrm{O}_{2} \rightarrow 12 \mathrm{CO}_{2}+11 \mathrm{H}_{2} \mathrm{O}
$$

Another role of sucrose in the preparation of $\mathrm{Gd}_{0.9} \mathrm{Sr}_{0.1} \mathrm{CoO}_{3}$ (solution-polymerization) is the formation of sacaric acid; which is obtained after its contact with citric acid. Sacaric acid is known to be a good chelating agent for metal ions, which produces a uniform distribution of cations throughout the polymeric network.

\subsection{Gas sensing characterization}

\subsubsection{Gas sensitivity curves}

About the gas sensing properties of $\mathrm{GdCoO}_{3}$ and $\mathrm{Gd}_{0.9} \mathrm{Sr}_{0.1} \mathrm{CoO}_{3}$, Fig. 12 shows the sensitivity curves obtained in $\mathrm{O}_{2}$ and $\mathrm{CO}_{2}$. Fig. 12A displays the graphs obtained from $\mathrm{GdCoO}_{3}$, whereas Fig. 12B corresponds to $\mathrm{Gd}_{0.9} \mathrm{Sr}_{0.1} \mathrm{CoO}_{3}$ (solution), and Fig. $12 \mathrm{C}$ to $\mathrm{Gd}_{0.9} \mathrm{Sr}_{0.1} \mathrm{CoO}_{3}$ (solution-polymerization). The sensitivity curves were obtained from the ratio: $R_{\text {gas }} / R_{\text {air }}$; where $R_{\text {gas }}$ is the resistance measured in the test gas $\left(\mathrm{O}_{2}\right.$ or $\left.\mathrm{CO}_{2}\right)$, and $R_{\text {air }}$ the resistance measured in dry air. Table 1 shows the temperatures at which the maximum sensitivity values were detected. From these results, sensitivity maxima occur at lower temperature in $\mathrm{Gd}_{0.9} \mathrm{Sr}_{0.1} \mathrm{CoO}_{3}$ (solution polymerization). Moreover, sensitivity maxima in $\mathrm{CO}_{2}$ are sharper than those obtained in $\mathrm{O}_{2}$; in the latter, broad curves were recorded instead. By comparing these results, with those reported from other materials such as $\mathrm{ZnO}$ and $\mathrm{SnO}_{2}$, $\mathrm{Gd}_{0.9} \mathrm{Sr}_{0.1} \mathrm{CoO}_{3}$ displays moderate gas sensitivity values. 

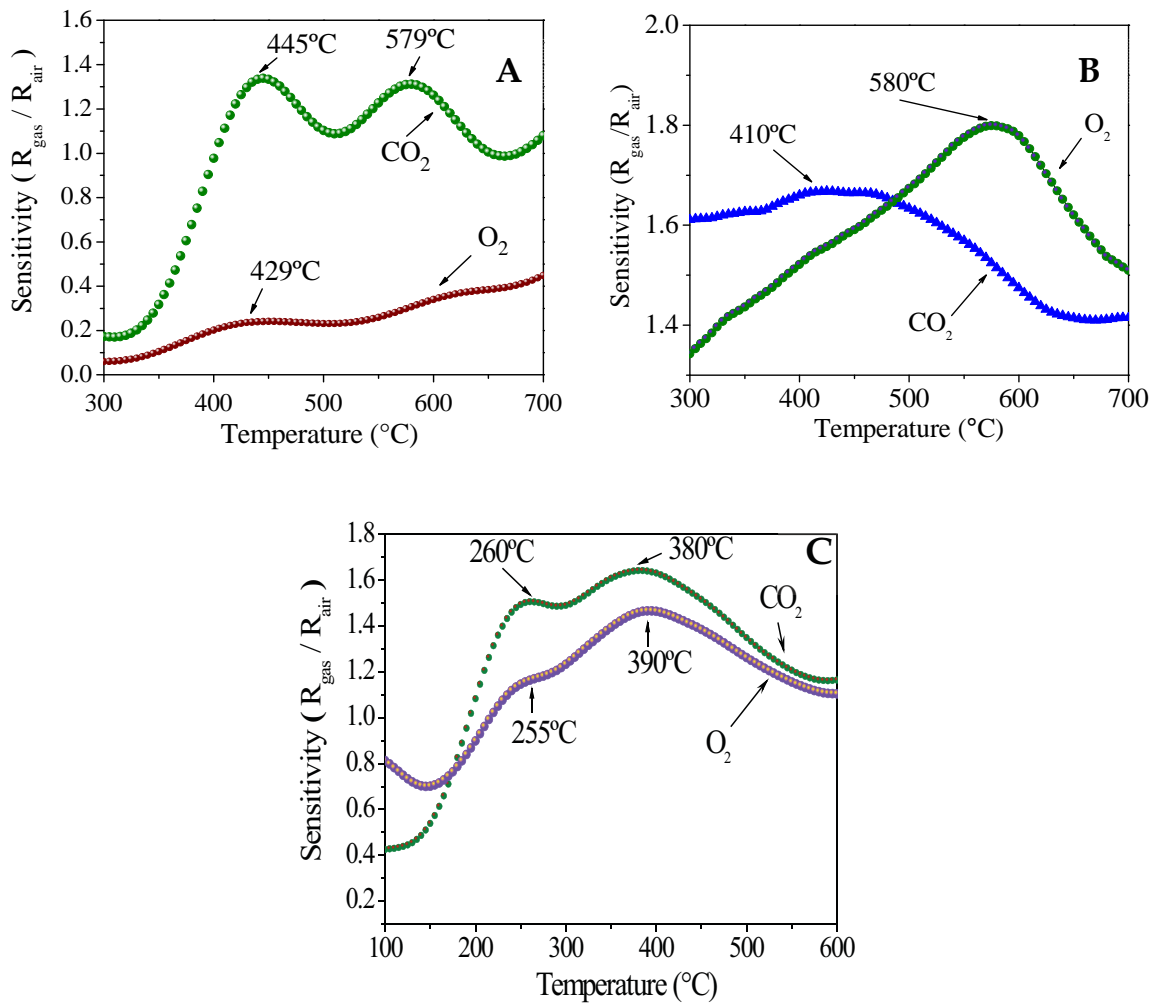

Fig. 12. Sensitivity vs. temperature plots recorded in $\mathrm{O}_{2}$ and $\mathrm{CO}_{2}$ for $\left.\mathrm{A}\right) \mathrm{GdCoO}$, B) $\mathrm{Gd}_{0.9} \mathrm{Sr}_{0.1} \mathrm{CoO}_{3}$ (solution method), and C) $\mathrm{Gd}_{0.9} \mathrm{Sr}_{0.1} \mathrm{CoO}_{3}$ (solution-polymerization).

\begin{tabular}{|c|c|c|c|c|}
\hline $\begin{array}{c}\text { Sensitivity } \\
\left(R_{\text {gas }} / R_{\text {air }}\right)\end{array}$ & \multicolumn{2}{|c|}{$\mathrm{O}_{2}$} & \multicolumn{2}{c|}{$\mathrm{CO}_{2}$} \\
\hline $\mathrm{GdCoO}_{3}$ & \multicolumn{2}{|c|}{$580^{\circ} \mathrm{C}$} & \multicolumn{2}{c|}{$410^{\circ} \mathrm{C}$} \\
\hline $\begin{array}{c}\mathrm{Gd}_{0.9} \mathrm{Sr}_{0.1} \mathrm{CoO}_{3} \\
(\text { solution})\end{array}$ & $429^{\circ} \mathrm{C}$ & $600^{\circ} \mathrm{C}$ & $445^{\circ} \mathrm{C}$ & $579^{\circ} \mathrm{C}$ \\
\hline $\begin{array}{c}\mathrm{Gd}_{0.9} \mathrm{Sr}_{0.1} \mathrm{CoO}_{3} \\
\text { (solution-polymerization) }\end{array}$ & $255^{\circ} \mathrm{C}$ & $390^{\circ} \mathrm{C}$ & $260^{\circ} \mathrm{C}$ & $380^{\circ} \mathrm{C}$ \\
\hline
\end{tabular}

Table 1. Temperatures of maximum sensitivity values recorded in $\mathrm{O}_{2}$ and $\mathrm{CO}_{2}$ for $\mathrm{Gd}_{1-\mathrm{x}} \mathrm{Sr}_{\mathrm{x}} \mathrm{CoO}_{3}$.

\subsubsection{Dynamic gas sensing response}

Fig. 13 shows resistance $v s$. time graphs recorded on $\mathrm{GdCoO}_{3}$, in: (A) air/100 ppm of $\mathrm{O}_{2}$ (in air), and (B) air/100 ppm of $\mathrm{CO}_{2}$ (in air). These tests were done at a fixed temperature, which correspond to the maximum sensitivity values shown in Table 1. Fig. 13 shows a decrease of $\mathrm{R}$ after the introduction of $\mathrm{O}_{2}$; in $\mathrm{CO}_{2}$ the opposite behavior was registered. The variation of resistance in $\mathrm{O}_{2}$ was $-6 \Omega$; whereas, in $\mathrm{CO}_{2}$ was $\sim 40 \Omega$. However, in $\mathrm{CO}_{2}$ the resistance did not stabilize. 

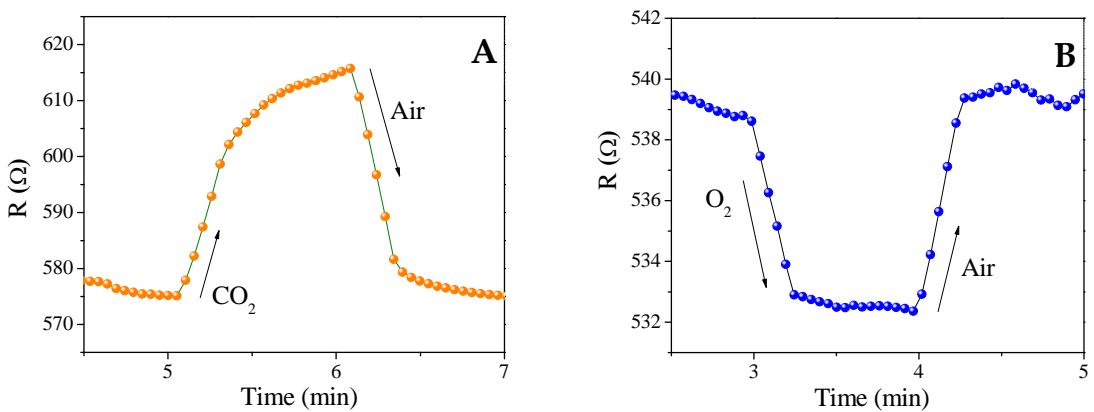

Fig. 13. Resistance vs. time graphs registered in air $/ \mathrm{O}_{2}\left(580^{\circ} \mathrm{C}\right)$, and air $/ \mathrm{CO}_{2}\left(410^{\circ} \mathrm{C}\right)$, for $\mathrm{GdCoO}_{3}$.

Fig. 14 shows $\mathrm{R}$ vs. time graphs recorded in: (A) air/100 ppm of $\mathrm{O}_{2}$ (in air), and (B) air/100 ppm of $\mathrm{CO}_{2}$ (in air), for $\mathrm{Gd}_{0.9} \mathrm{Sr}_{0.1} \mathrm{CoO}_{3}$ prepared by solution and solution-polymerization. These measurements were performed at $380^{\circ} \mathrm{C}$, which is an intermediate sensitivity value. This temperature was chosen in order to compare the results obtained from different $\mathrm{Gd}_{0.9} \mathrm{Sr}_{0.1} \mathrm{CoO}_{3}$ samples. Compared to the graphs of Fig. 13, the resistance decreased about one order of magnitude. $\mathrm{Gd}_{0.9} \mathrm{Sr}_{0.1} \mathrm{CoO}_{3}$ (solution-polymerization) displayed the largest variation of resistance; however, the stabilization of resistance with time was not observed. $\mathrm{Gd}_{0.9} \mathrm{Sr}_{0.1} \mathrm{CoO}_{3}$ (solution method), displays stabilization of resistance in both gases; however, further experiments demonstrated that $\mathrm{Gd}_{0.9} \mathrm{Sr}_{0.1} \mathrm{CoO}_{3}$ (solution-polymerization) exhibited a better gas sensing performance.
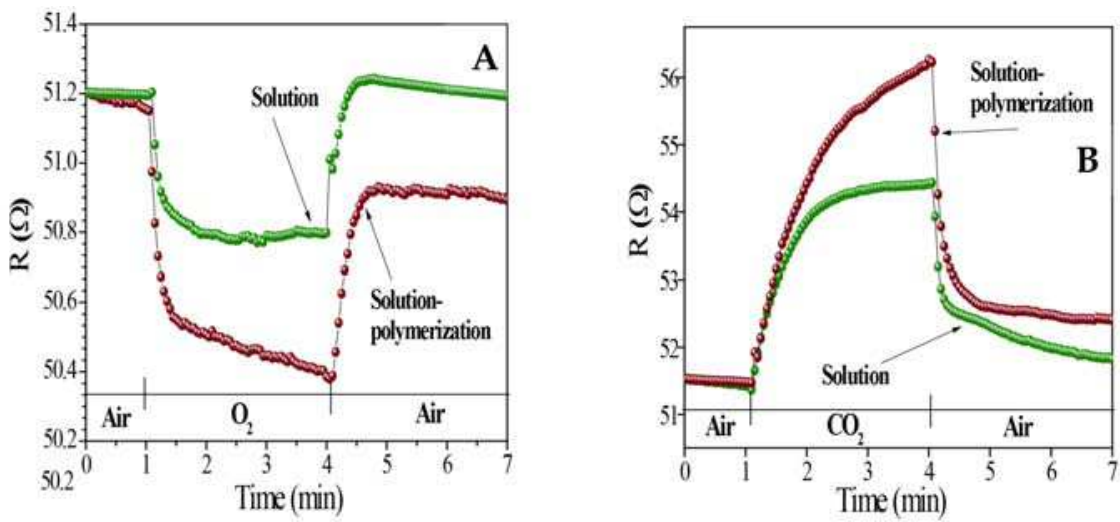

Fig. 14. Resistance vs. time graphs recorded in: (A) air $/ \mathrm{O}_{2}$, and (B) air $/ \mathrm{CO}_{2}$, for $\mathrm{Gd}_{0.9} \mathrm{Sr}_{0.1} \mathrm{CoO}_{3}$ prepared by solution and solution-polymerization methods $\left(380^{\circ} \mathrm{C}\right)$.

Fig. $15 \mathrm{~A}$ shows the variation of resistance with time measured when air, $\mathrm{CO}_{2}$ and $\mathrm{O}_{2}$ were alternatively supplied. This experiment was made in order to test the gas selectivity of $\mathrm{Gd}_{0.9} \mathrm{Sr}_{0.1} \mathrm{CoO}_{3}$ prepared by solution-polymerization. Fig. 15A shows a combination of the results displayed in Fig. 14; having a decrease of $\mathrm{R}$ in oxygen, and the opposite behavior in carbon dioxide. The variation of resistance registered in each gas was nearly the same to that observed in Fig. 14. The response pattern of Fig. 15 was highly reproducible, revealing also that the gas detection involves reversible processes. 

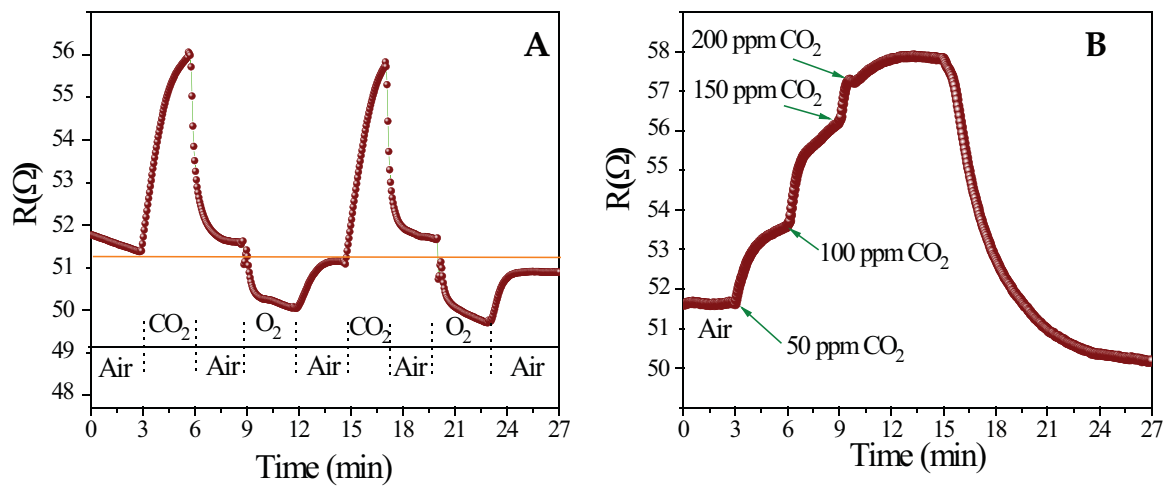

Fig. 15. Resistance vs. time plots acquired in: (A) air, $\mathrm{CO}_{2}$ and $\mathrm{O}_{2}$; and (B) different concentrations of $\mathrm{CO}_{2}\left(380^{\circ} \mathrm{C}\right)$.

Fig. 15B displays the ability of $\mathrm{Gd}_{0.9} \mathrm{Sr}_{0.1} \mathrm{CoO}_{3}$ to detect variations in the concentration of $\mathrm{CO}_{2}$. In this experiment, dry air was supplied for about $10 \mathrm{~min}$, until stable resistance measurements were obtained. Then, $\mathrm{CO}_{2}$ with a concentration of $50 \mathrm{ppm}$ was injected; this produced an increase of $\mathrm{R}$ of about $2 \Omega$. Later, the concentration of $\mathrm{CO}_{2}$ was increased to $100 \mathrm{ppm}$, which increased $\mathrm{R}$ in $\sim 2.5 \Omega$. This result agrees with that shown in Fig. 14B; however, when the concentration of $\mathrm{CO}_{2}$ was increased to 150 and $200 \mathrm{ppm}$, smaller increments of $\mathrm{R}$ were registered. The latter suggests that the concentration limit at which $\mathrm{Gd}_{0.9} \mathrm{Sr}_{0.1} \mathrm{CoO}_{3}$ can satisfactorily detect $\mathrm{CO}_{2}$ is 100 ppm. However, for large concentrations, a saturated state was observed. This behavior can be attributed to several factors, which include surface area, gas diffusivity and temperature, among others. On the other hand, this kind of experiment was also performed to detect variations in the concentration of $\mathrm{O}_{2}$; however, unreliable results were produced. Future improvements on the gas sensor device may result in a better performance in oxygen. Therefore, polarization curves were focused on the ability of $\mathrm{Gd}_{0.9} \mathrm{Sr}_{0.1} \mathrm{CoO}_{3}$ to detect variations in the concentration of $\mathrm{CO}_{2}$.

\subsubsection{Polarization curves}

Polarization curves (or I-V curves), were recorded to test the ability to detect changes in the concentration of $\mathrm{CO}_{2}$ (static mode). These curves were obtained at $380^{\circ} \mathrm{C}$, using $\mathrm{CO}_{2}$ at concentrations of 50,100, 150 and $200 \mathrm{ppm}$. Measurements in air were also performed to obtain a reference curve. Fig. 16 shows typical I $-\mathrm{V}$ curves recorded from $-5 \mathrm{~V}$ to $5 \mathrm{~V}$. It is worth to mention that beyond this voltage range, reliable measurements were not acquired. These curves show that the presence of $\mathrm{CO}_{2}$ produced an abrupt decrease of current. This is in agreement with the results presented in the previous section, where $\mathrm{CO}_{2}$ increased the resistance. By increasing the concentration of $\mathrm{CO}_{2}$, smaller values of current were registered; at both cathodic and anodic voltages.

On the other hand, the nonlinear behavior of I-V curves of Fig. 16 is similar to that reported for varistor gas sensors. According to Lin et al., the increase of nonlinearity of I-V curves of varistor gas sensors is caused by the decrease of grain size (Lin et al., 1995). Due to the small 


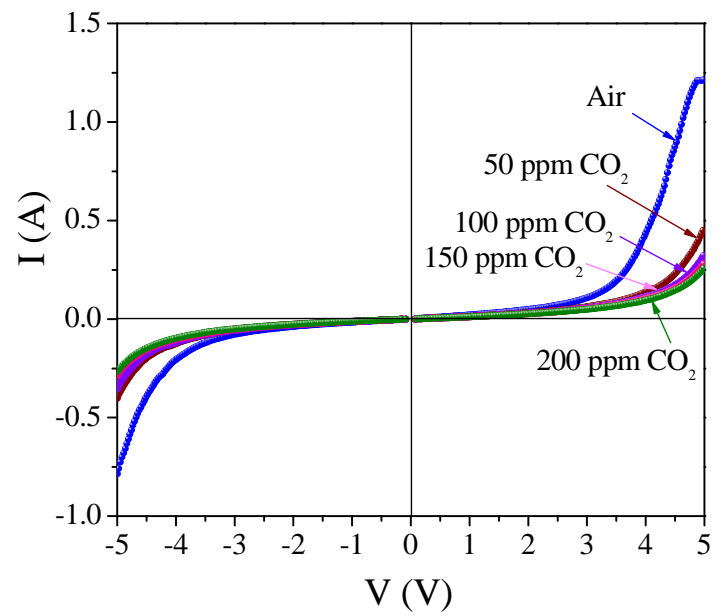

Fig. 16. Polarization curves obtained at different concentrations of $\mathrm{CO}_{2}$, on $\mathrm{Gd}_{0.9} \mathrm{Sr}_{0.1} \mathrm{CoO}_{3}$ films $\left(380^{\circ} \mathrm{C}\right)$.

particle size of $\mathrm{Gd}_{0.9} \mathrm{Sr}_{0.1} \mathrm{CoO}_{3}$ (solution-polymerization), the nonlinearity of $\mathrm{I}-\mathrm{V}$ curves is similar to that reported by Lin and coworkers.

\subsubsection{Dynamic gas sensing response in alternating current}

Another useful approach to analyze the gas sensing properties of materials, is by means of the use of alternating current. One of the advantages of using alternating current is that some materials respond satisfactorily to gases, at high frequencies, but not at direct current. In the present experiments, the magnitude of the impedance $(|\mathrm{Z}|)$ was measured using several frequencies, from $100 \mathrm{~Hz}$ to $100 \mathrm{kHz}$. The amplitude of the signal was $1 \mathrm{~V}$. From several results it was observed that the best graphs were recorded at $100 \mathrm{kHz}$.

Fig. 17 shows $|\mathrm{Z}|$ vs. time graphs obtained after the successive injection of air and 50 ppm $\mathrm{O}_{2}\left(100 \mathrm{kHz}, 380^{\circ} \mathrm{C}\right)$. The difference between the graphs $17 \mathrm{~A}$ and $17 \mathrm{~B}$ is the exposition time to the test gas. One of the reasons to perform these experiments was to investigate if the stabilization of $|\mathrm{Z}|$ can be obtained after a prolonged exposition to the test gas. Fig. 17B shows that the longer exposition to $50 \mathrm{ppm} \mathrm{O}_{2}$ produced a continuous decrease of $|Z|$; which is in agreement with Fig. 14A. The incomplete desorption of oxygen may be explained by the fact that $\mathrm{Gd}_{0.9} \mathrm{Sr}_{0.1} \mathrm{CoO}_{3}$ possess oxygen vacancies in its crystal structure, which is commom in transition metal oxides with the perovskitetype structure. Is possible that part of the oxygen supplied in these tests occupies the oxygen vacancies of $\mathrm{Gd}_{0.9} \mathrm{Sr}_{0.1} \mathrm{CoO}_{3}$. About this issue, it is well known that the oxygenation of $\mathrm{YBa}_{2} \mathrm{Cu}_{3} \mathrm{O}_{7-\delta}$ produces the high $\mathrm{T}_{c}$ superconducting phase; which indicates the ability of perovskites to retain oxygen. The stabilization of $|Z|$ with time was not observed in these experiments, but some improvements in the gas sensor device may enhace the detection of $\mathrm{O}_{2}$. These improvements include the increase in the surface contact between the metal electrode and the oxide powder. Another relevant issue is the use of gold or platinum as electrodes. 

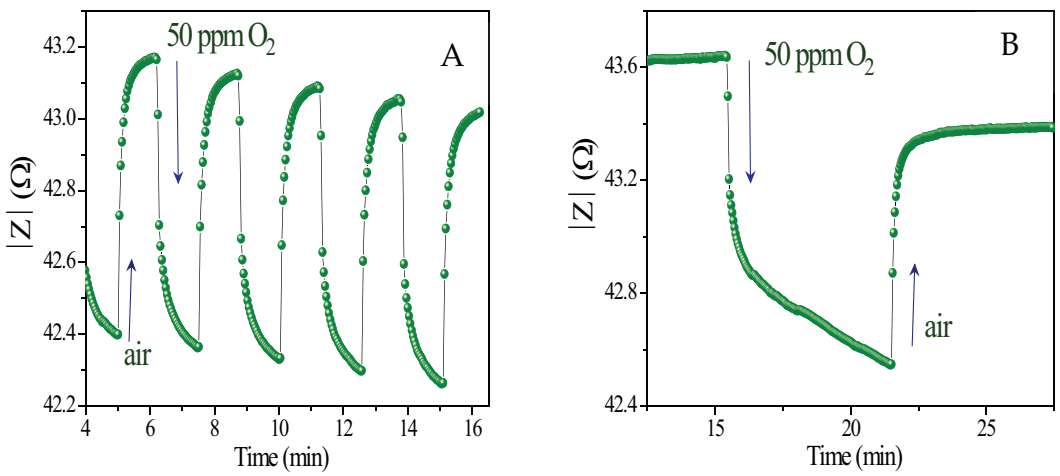

Fig. 17. $|\mathrm{Z}|$ vs. time plots recorded at different exposition times to $50 \mathrm{ppm} \mathrm{O}_{2}(100 \mathrm{kHz}$, $\left.380^{\circ} \mathrm{C}\right)$.

Fig. 18 shows typical results obtained when a film of $\mathrm{Gd}_{0.9} \mathrm{Sr}_{0.1} \mathrm{CoO}_{3}$ was exposed to air and $50 \mathrm{ppm} \mathrm{CO} 2\left(100 \mathrm{kHz}, 380^{\circ} \mathrm{C}\right)$. Analogously to the previous results, the difference between the figures $18 \mathrm{~A}$ and $18 \mathrm{~B}$ is the exposition time to $\mathrm{CO}_{2}$. Notable repeatibility in the detection of $\mathrm{CO}_{2}$ can be observed in Fig. 18A. Full recovery of the original $|\mathrm{Z}|$ value can also be noticed. Fig. 18B revealed a lack of a saturated state, similar to that observed in oxygen. Even so, we can conclude that a better performance in $\mathrm{CO}_{2}$ was obtained.

Fig. 19 shows $|\mathrm{Z}|$ vs. time graphs acquired at different concentrations of: (A) oxygen and (B) carbon dioxide. It is worth to mention that these experiments were also performed at direct current; however, the results were far to be satisfactory, and they were not included in this work. Fig. 19 reveals that the increase of the gas concentration in $50 \mathrm{ppm}$ produced a proportional variation of $|Z|$. In oxygen, a continuous decrease of $|Z|$ with time can be observed; which is more attenuated in carbon dioxide. In summary, based in the preceding results, $\mathrm{Gd}_{0.9} \mathrm{Sr}_{0.1} \mathrm{CoO}_{3}$ can be considered as an alternativey $\mathrm{CO}_{2}$ sensor material. As an oxygen gas sensor material, a rather limited performance was observed.
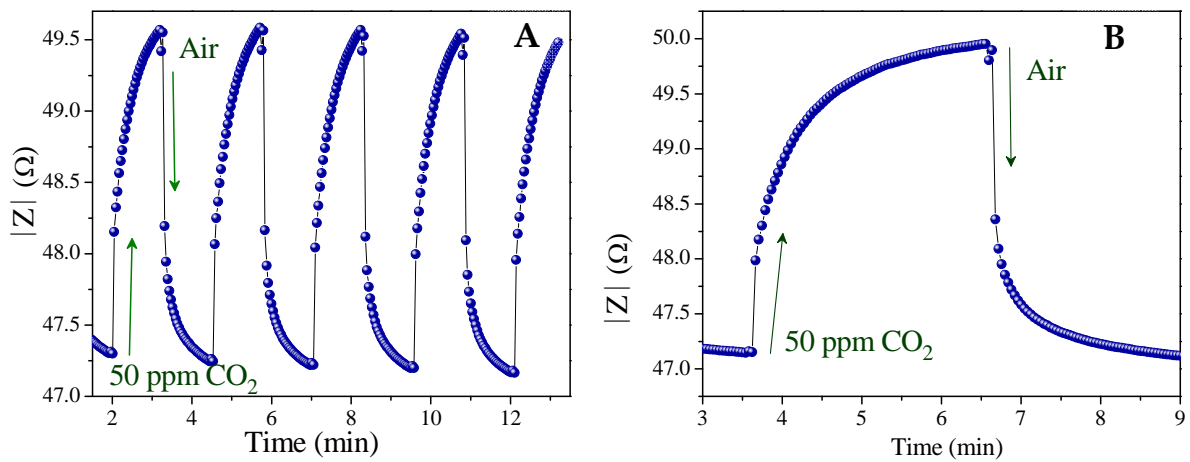

Fig. 18. $|\mathrm{Z}|$ vs. time graphs acquired using two different exposition times to $50 \mathrm{ppm} \mathrm{CO}_{2}$ $\left(100 \mathrm{kHz}, 380^{\circ} \mathrm{C}\right)$. 

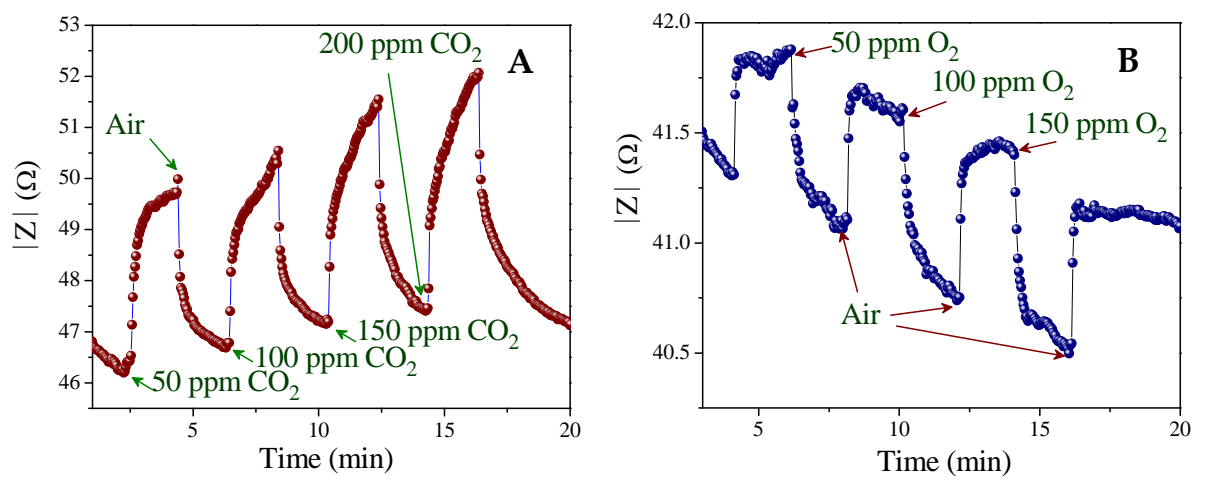

Fig. 19. $|\mathrm{Z}|$ vs. time graphs acquired at different concentrations of $(\mathrm{A}) \mathrm{O}_{2}$ and (B) $\mathrm{CO}_{2}(100$ $\left.\mathrm{kHz}, 380^{\circ} \mathrm{C}\right)$.

\subsection{Gas sensing mechanisms}

The explanation of the gas sensing mechanism in semiconductor oxides is frequently based in the change of resistance (or impedance) produced by adsorption processes. It has been reported in the literature that gas adsorption depends, among others, on the operation temperature, particle size, specific surface area and gas partial pressure.

Oxide semiconductors can be classified as p-type or n-type, according to the variation of conductivity caused by a reducing or oxidizing gas (Moseley, et al., 1991). In an oxidizing atmosphere, a p-type semiconductor material adsorbs oxygen molecules. These molecules capture electrons, increasing the number of charge carriers (holes). As a result, the electrical conductivity increases (Baraton, et al., 2003). The oxygen adsorption can occur by means of one of the following reactions:

$$
\begin{gathered}
\mathrm{O}_{2} \text { (gas) }+\mathrm{e}^{-} \rightarrow \mathrm{O}_{2}^{-} \text {(ads) } \\
\mathrm{O}_{2}(\text { gas })+2 \mathrm{e}^{-} \rightarrow 2 \mathrm{O}^{-} \text {(ads) } \\
\mathrm{O}_{2} \text { (gas) }+4 \mathrm{e}^{-} \rightarrow 2 \mathrm{O}^{2-}(\text { ads })
\end{gathered}
$$

About the $\mathrm{CO}_{2}$ gas sensing mechanism, the increase of $|\mathrm{Z}|$ suggests a change in the dielectric constant $(\kappa)$ of the film. $\mathrm{CO}_{2}$ can not be adsorbed on the surface of $\mathrm{Gd}_{0.9} \mathrm{Sr}_{0.1} \mathrm{CoO}_{3}$ because is a stable molecule. The formation of a thin layer of carbonate decreases $\kappa$, due to the dielectric constant of carbonates is frequently smaller than the oxides (Ishihara, et al., 1991). The decrease of $|Z|$ with $\kappa$ can be explained in terms of the following equation:

$$
|Z|=\sqrt{R^{2}+\left(\frac{1}{\kappa \omega C_{o}}\right)^{2}}
$$


Where $\mathrm{R}$ is the electrical resistance, $\kappa$ is the dielectric constant, $\omega$ is the angular frequency and $C_{o}$ is the capacitance in air (Halliday, et al., 2001). The decrease of $\kappa$ produces the increase of $|Z|$; then, when air is reintroduced, $|Z|$ returns to its original value. Some authors have studied the formation of bicarbonate, bidentate or monodentate on $\mathrm{MgO}, \mathrm{CaO}$ and $\mathrm{ZrO}_{2}$ (Tsuji, et al., 2003); however, the identification of the specific type of carbonate formed on $\mathrm{Gd}_{0.9} \mathrm{Sr}_{0.1} \mathrm{CoO}_{3}$ is currently investigated.

On the other hand, some authors have reported that the process by which charge carriers are transported through a material, depends on the particle size (Bochenkov, et al., 2005). First, the thickness of the charged layer $\left(\mathrm{L}_{\mathrm{S}}\right)$ depends on the surface potential $\left(\mathrm{V}_{\mathrm{S}}\right)$, according to the equation:

$$
\mathrm{L}_{\mathrm{S}}=\mathrm{L}_{\mathrm{D}} \sqrt{\frac{\mathrm{eV}_{\mathrm{S}}^{2}}{\mathrm{kT}}}
$$

Where $L_{D}$ is the Debye length, e is the electron charge, $\mathrm{k}$ is the Boltzmann's constant and T is the temperature. $L_{D}$ depends on other physical parameters through the following relation:

$$
L_{D}=\sqrt{\frac{\kappa k T}{2 \pi e^{2} N_{d}}}
$$

Where $\kappa$ is the dielectric constant and $N_{d}$ is the concentration of donor impurity. Typical values of $L_{s}$ are in the range 1 to $100 \mathrm{~nm}$. If $\mathrm{D}$ is the crystallite size, three possible mechanisms are usually proposed:

1. $\mathrm{D}>>2 \mathrm{~L}_{\mathrm{S}}$, the conductance is limited by Schottky barriers

2. $\mathrm{D}=2 \mathrm{~L}_{\mathrm{S}}$, the conductivity is controlled by the necks formed among particles

3. $\mathrm{D}<2 \mathrm{~L}_{\mathrm{S}}$, in this case the entire volume of each crystallite participates in the charge transport

Fig. 20 shows a schematic illustration of the last two mechanisms. The dark green area represents the volume through which charge carriers move. The third mechanism may be a possible explanation of the improved gas sensing behavior in nanostructured $\mathrm{Gd}_{0.9} \mathrm{Sr}_{0.1} \mathrm{CoO}_{3}$ (solution-polymerization).

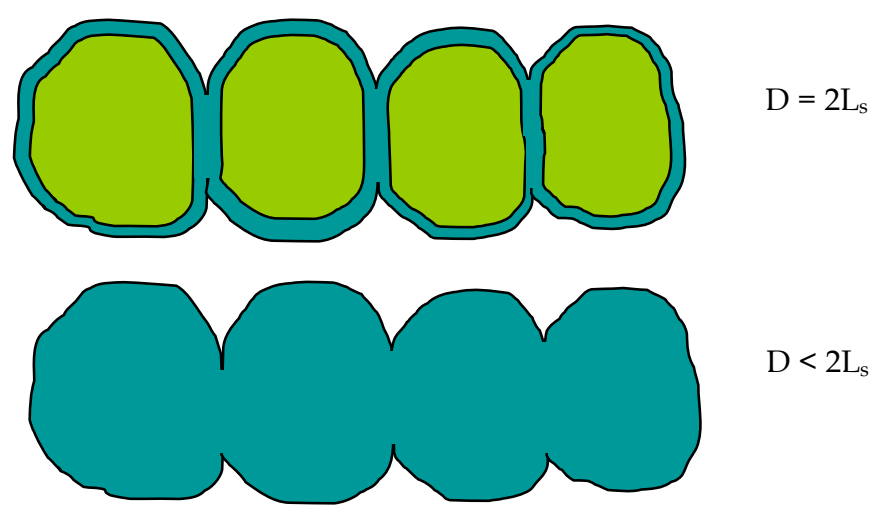

Fig. 20. Scheme of two mechanisms of conductance in semiconductor materials. 


\section{Conclusions}

The solution-polymerization process is a simple and cost effective method for preparing nanostructured $\mathrm{Gd}_{0.9} \mathrm{Sr}_{0.1} \mathrm{CoO}_{3}$. Due to PVA and sucrose are inexpensive materials, this method can be used to obtain other nanostructured compounds; which can be used in fields like gas sensors, gas separation membranes, electrodes for solid oxide fuel cells and catalysis, to mention a few. In this work, single phase $\mathrm{Gd}_{0.9} \mathrm{Sr}_{0.1} \mathrm{CoO}_{3}$ prepared by solutionpolymerization was obtained from $600^{\circ} \mathrm{C}$. However, by the solution method, it was obtained at $800^{\circ} \mathrm{C}$. Extensive porosity caused by the decomposition of PVA and sucrose, as well as lower calcination temperatures, produced a nanostructured network of $\mathrm{Gd}_{0.9} \mathrm{Sr}_{0.1} \mathrm{CoO}_{3}$. The latter was observed by transmission electron microscopy.

Through the analysis of the gas sensing results it was possible to conclude that $\mathrm{Gd}_{0.9} \mathrm{Sr}_{0.1} \mathrm{CoO}_{3}$ (solution-polymerization), detects oxygen and carbon dioxide at lower operation temperature. The stability and repeatability observed in the detection of $\mathrm{CO}_{2}$ was notably enhanced when alternating current was used. However, the stability in the detection of $\mathrm{O}_{2}$ needs improvements in the gas sensor device. The response and recovery times as a function of operation temperature are important parameters and are under investigation.

According to recent publications, the decrease of particle size, at the nanometer scale, causes that charge carriers are transported through the entire volume of the crystallites. This is relevant in solid state gas sensor materials because small resistance changes can be detected using standard instrumentation.

\section{Acknowledgment}

Financial support from the Coordinación General Académica of the Universidad de Guadalajara and COECYTJAL (Grant PS-2008-847) is greatly acknowledged. The authors are grateful to CONACYT for two doctorate scholarships (N.L.L.C. and E.R.L.M.).

\section{References}

Baraton, M.I. \& Merhari L. (2003). Electrical Behavior of Semiconducting Nanopowders versus Environment, Rev. Adv. Mater. Sci. Vol. 4, pp. 15-24.

Bochenkov, V.E. \& Sergeev G.B. (2005). Preparation and Chemiresistive Properties of Nanostructured Materials, Adv. Colloid. Interface Sci. Vol. 116, pp. 245-254.

Brosha, E.L.; Mukindan, R.; Brown, D.R.; Garzon, F.H.; Visser, J.H.; Zanini, M.; Zhou, Z. \& Logothetis, E.M. (2000). CO/HC Sensors Based on Thin Films of $\mathrm{LaCoO}_{3}$ and $\mathrm{La}_{0.8} \mathrm{Sr}_{0.2} \mathrm{CoO}_{3-\delta}$ Metal Oxides, Sens. Actuators B, Vol. 69, pp. 171-182.

Das, R.N. (2001). Nanocrystalline Ceramics from Sucrose Process, Mater. Lett. Vol. 47, pp. 344-350.

Dutta, A.; Ishihara, T.; Nishiguchi, H. \& Takita Y. (2004). Amperometric Solid-State Gas Sensor using $\mathrm{LaGaO}_{3}$ Based Perovskite Oxide Electrolyte for Detecting Hydrocarbon in Exhaust Gas, J. Electrochem. Soc. Vol. 151, pp. H122-H127.

Halliday, D.; Resnick, R. \& Walker, J. (2001). Fundamentals of Physics, Wiley, New York, USA. 
Karl, T.R. \& Trenberth, K.E. (2003). Modern Global Climate Change, Science, Vol. 302, pp. 1719-1723.

Kerr, R.A. (2007). Global Warming is Changing the World, Science, Vol. 316, pp. 188-190.

Kong, L.B. \& Shen, Y.S. (1996). Gas-Sensing Property and Mechanism of $\mathrm{Ca}_{x} \mathrm{La}_{1-x} \mathrm{FeO}_{3}$ Ceramics, Sens. Actuators B, Vol. 30 pp. 217-221.

Kosacki, I. \& Anderson, H.U. (1998). Nanostructured Oxide Thin Films for Gas Sensors, Sens. Actuators B, Vol. 48, pp. 263-269.

Gülgün, M.A.; Nguyen, M.H. \& Kriven, W.M. (1999) Polymerized Organic-Inorganic Synthesis of Mixed Oxides, J. Am. Ceram. Soc. Vol. 82, pp. 556-560.

Ishihara, T.; Kometani, K.; Hashida, M. \& Takita, Y. (1991) Application of Mixed Oxide Capacitor to the Selective Carbon Dioxide Sensor, J. Electrochem. Soc. Vol. 138, pp. 173-176.

Lee, S.J. \& Kriven, W.M. (1998) Crystallization and Densification of Nano-Size Amorphous Cordierite Powder Prepared by a PVA Solution-Polymerization Route, J. Am. Ceram. Soc. Vol. 81, pp. 2605-2612.

Lin, F.C.; Takao, Y.; Shimizu, Y. \& Egashira, M. (1995) Zinc Oxide Varistor Gas Sensors: Effect of $\mathrm{Bi}_{2} \mathrm{O}_{3}$ Content on the $\mathrm{H}_{2}$-Sensing Properties, J. Am. Ceram. Soc. Vol. 78, pp. 2301-2306.

Mahata, P.; Aarti, T.; Madras, G. \& Natarajan, S. (2007) Photocatalytic Degradation of Dyes and Organics with Nanosized $\mathrm{GdCoO}_{3}$, J. Phys. Chem. C, Vol. 111, pp. 1665-1674.

Michel, C.R.; Martínez, A.H. \& Morán, J.P. (2009). Carbon Dioxide Gas Sensing Behavior of Nanostructured $\mathrm{GdCoO}_{3}$ Prepared by a Solution-Polymerization Method, J. Alloy. Compd. Vol. 484, pp. 605-611.

Moon, J.W.; Seo, W.S.; Okabe, H.; Okawa, T. \& Koumoto, K. (2000). Ca-Doped $\mathrm{RCoO}_{3}(\mathrm{R}=$ Gd, Sm, Nd, Pr) as Thermoelectric Materials, J. Mater. Chem. Vol. 10, pp. 2007-2009.

Moseley P.T.; Stoneham, A.M. \& Williams, D.E. (1991). Techniques and Mechanisms in Gas Sensing, Adam Hilger, Bristol, UK.

Parry, M.; Canziani, O. \& Palutikof, J. (2008). Key IPCC Conclusions on Climate Change Impacts and Adaptations, World Meteorological Organization Bulletin, Vol. 57, pp. 7885.

Post, M.L.; Tunney, J.J.; Yang, D.; Du, X. \& Singleton D.L. (1999). Material Chemistry of Perovskite Compounds as Chemical Sensors, Sens. Actuators B, Vol. 59, pp. 190-194.

Rey-Cabezudo, C.; Sánchez-Andújar, M.; Mira, J. Fondado, A.; Rivas, J. \& SeñarísRodríguez, M.A. (2002). Magnetotransport in $\mathrm{Gd}_{1-x} \mathrm{Sr}_{x} \mathrm{CoO}_{3}(0<x<0.30)$ Perovskites, Chem. Mater. Vol. 14, pp. 493-498.

Suo, H.; Wu, F.; Wang, Q.; Liu, G.; Qiu, F.; Xu, B. \& Zhao M. (1997). Influence of Sr Content on the Ethanol Sensitivity of Nanocrystalline $\mathrm{La}_{1 \sim x} \mathrm{Sr}_{x} \mathrm{FeO}_{3}$, J. Solid State Chem. Vol. 130, pp. 152-153.

Takeda, Y.; Ueno, H.; Imanishi, N.; Yamamoto, O.; Sammes, N. \& Phillipps, M.B. (1996). Gd 1- $_{1-}$ ${ }_{x} \mathrm{Sr}_{x} \mathrm{CoO}_{3}$ for the Electrode of Solid Oxide Fuel Cells, Solid State Ionics, Vol. 86-88, pp. 1187-1190.

Tsuji, H.; Okamura-Yoshida, A.; Shishido, T. \& Hattori, H. (2003) Dynamic Behavior of Carbonate Species on Metal Oxide Surfaces: Oxygen Scrambling Between Adsorbed Carbon Dioxide and Oxide Surface, Langmuir, Vol. 19 pp. 8793-8800.

Wang, C.C.; Akbar, S.A. \& Madou M.J. (1998). Ceramic Based Resistive Sensors, J. Elecroceram. Vol. 2:4, pp. 273-282. 
Wienhöfer, H.D.; Bremes, H.G. \& Nigge, U. (2004) Mixed Conduction and Electrode Properties of Doped Cobaltites and Chromites, Solid State Ionics, Vol. 175, pp. 93-98. Yamazoe, N. (2005). Toward Innovations of Gas Sensor Technology, Sens. Actuators B, Vol. 108 , pp. 2-14. 


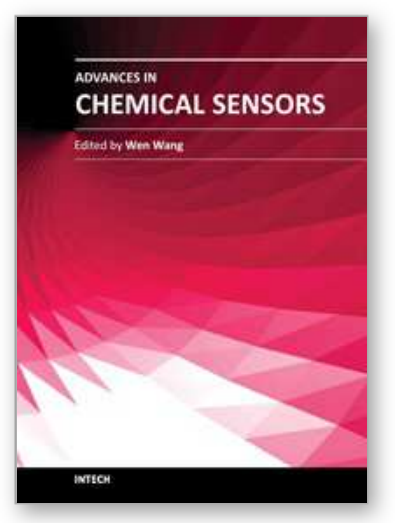

\author{
Advances in Chemical Sensors \\ Edited by Prof. Wen Wang
}

ISBN 978-953-307-792-5

Hard cover, 358 pages

Publisher InTech

Published online 20, January, 2012

Published in print edition January, 2012

The chemical sensor plays an essential role in the fields of environmental conservation and monitoring, disaster and disease prevention, and industrial analysis. A typical chemical sensor is a device that transforms chemical information in a selective and reversible way, ranging from the concentration of a specific sample component to total composition analysis, into an analytically useful signal. Much research work has been performed to achieve a chemical sensor with such excellent qualities as quick response, low cost, small size, superior sensitivity, good reversibility and selectivity, and excellent detection limit. This book introduces the latest advances on chemical sensors. It consists of 15 chapters composed by the researchers active in the field of chemical sensors, and is divided into 5 sections according to the classification following the principles of signal transducer. This collection of up-to-date information and the latest research progress on chemical sensor will provide valuable references and learning materials for all those working in the field of chemical sensors.

\title{
How to reference
}

In order to correctly reference this scholarly work, feel free to copy and paste the following:

Carlos R. Michel, Narda L. López Contreras, Edgar R. López-Mena, Juan Carlos Ibarra, Arturo ChávezChávez and Mauricio Ortiz-Gutiérrez (2012). Improvement of the Gas Sensing Properties in Nanostructured Gd0.9Sr0.1CoO3, Advances in Chemical Sensors, Prof. Wen Wang (Ed.), ISBN: 978-953-307-792-5, InTech, Available from: http://www.intechopen.com/books/advances-in-chemical-sensors/improvement-of-the-gassensing-properties-in-nanostructured-gd0-9sr0-1coo3

\section{INTECH}

open science | open minds

\section{InTech Europe}

University Campus STeP Ri

Slavka Krautzeka 83/A

51000 Rijeka, Croatia

Phone: +385 (51) 770447

Fax: +385 (51) 686166

www.intechopen.com

\section{InTech China}

Unit 405, Office Block, Hotel Equatorial Shanghai

No.65, Yan An Road (West), Shanghai, 200040, China 中国上海市延安西路65号上海国际贵都大饭店办公楼 405 单元

Phone: +86-21-62489820

Fax: $+86-21-62489821$ 
(C) 2012 The Author(s). Licensee IntechOpen. This is an open access article distributed under the terms of the Creative Commons Attribution 3.0 License, which permits unrestricted use, distribution, and reproduction in any medium, provided the original work is properly cited. 